\title{
Correction to: Nationwide genetic testing towards eliminating Lafora disease from Miniature Wirehaired Dachshunds in the United Kingdom
}

Saija Ahonen ${ }^{1}$, lan Seath ${ }^{3}$, Clare Rusbridge ${ }^{4,5}$, Susan Holt ${ }^{3}$, Gill Key ${ }^{3}$, Travis Wang ${ }^{1}$, Peixiang Wang ${ }^{1}$ and Berge A. Minassian ${ }^{1,2^{*}}$

\section{Correction to: Canine Genet Epidemiol 5, 2 (2018)} https://doi.org/10.1186/s40575-018-0058-8

Following the publication of the original article [1], the authors identified an error in Fig. 1. The correct figure is given below and the original article has been corrected.

\begin{abstract}
Author details
${ }^{1}$ Program in Genetics and Genome Biology, The Hospital for Sick Children, 555 University Avenue, Toronto, ON M5G 1X8, Canada. ${ }^{2}$ Department of Pediatrics, University of Texas Southwestern, 5323 Harry Blvd, Dallas, TX 75390-9063, USA. ${ }^{3}$ Dachshund Breed Council, Wrington, North Somerset, UK. ${ }^{4}$ Fitzpatrick Referrals Orthopedics and Neurology, Halfway Lane, Eashing, Godalming, Surrey, UK. ${ }^{5}$ School of Veterinary Medicine, Faculty of Health \& Medical Sciences, University of Surrey, Guildford, Surrey, UK.
\end{abstract}

Published online: 27 December 2021

\section{Reference}

1. Ahonen $\mathrm{S}$, et al. Nationwide genetic testing towards eliminating Lafora disease from Miniature Wirehaired Dachshunds in the United Kingdom. Canine Genet Epidemiol. 2018;5:2.

* Correspondence: berge.minassian@utsouthwestern.edu

${ }^{1}$ Program in Genetics and Genome Biology, The Hospital for Sick Children, 555 University Avenue, Toronto, ON M5G 1X8, Canada

${ }^{2}$ Department of Pediatrics, University of Texas Southwestern, 5323 Harry Blvd, Dallas, TX 75390-9063, USA

Full list of author information is available at the end of the article

(C) The Author(s). 2021 Open Access This article is licensed under a Creative Commons Attribution 4.0 International License, which permits use, sharing, adaptation, distribution and reproduction in any medium or format, as long as you give appropriate credit to the original author(s) and the source, provide a link to the Creative Commons licence, and indicate if changes were made. The images or other third party material in this article are included in the article's Creative Commons licence, unless indicated otherwise in a credit line to the material. If material is not included in the article's Creative Commons licence and your intended use is not permitted by statutory regulation or exceeds the permitted use, you will need to obtain permission directly from the copyright holder. To view a copy of this licence, visit http://creativecommons.org/licenses/by/4.0/. The Creative Commons Public Domain Dedication waiver (http://creativecommons.org/publicdomain/zero/1.0/) applies to the data made available in this article, unless otherwise stated in a credit line to the data. 


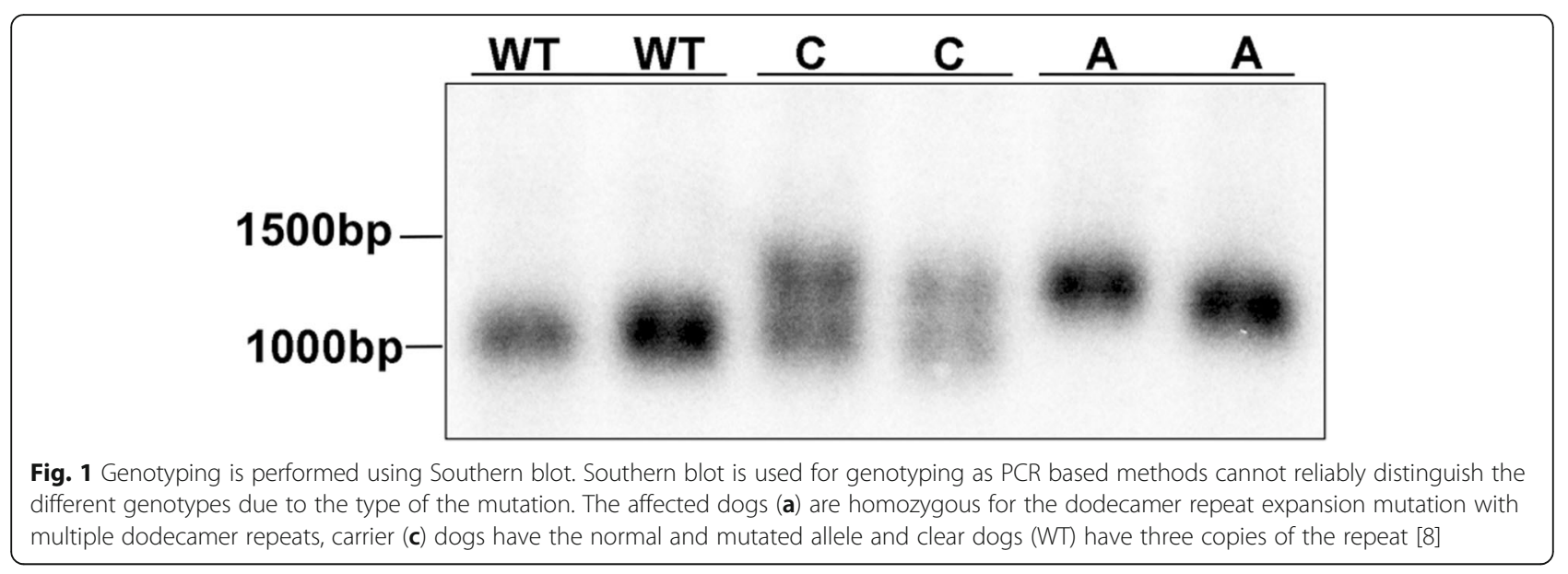

